\title{
Results and generalizability of the Target Temperature Management Trial and future research for patients admitted to intensive care after cardiac arrest
}

Niklas Nielsen

From Targeted Temperature Management (TTM 2014)

Berlin, Germany. 6-7 November 2014

The Target Temperature Management (TTM) Trial randomized 950 unconscious, adult patients with return of spontaneous circulation after out-of-hospital cardiac arrest (CA) of presumed cardiac cause to strict temperature management at either $33^{\circ} \mathrm{C}$ or $36^{\circ} \mathrm{C}$. Temperature was managed with intravascular or surface cooling devices for 36 hours, while the patients were sedated and mechanically ventilated. Prognostication and decisions on life-sustaining treatments were postponed until 4.5 to 5 days after CA in the general case [1]. There was no difference in the primary outcome: survival until the end of the trial (mortality $50 \%$ in the $33^{\circ} \mathrm{C}$ group and $48 \%$ in the $36^{\circ} \mathrm{C}$ group, hazard ratio $1.06,95 \%$ confidence interval 0.89 to $1.28, p=0.51$ ) or the secondary outcomes: neurological function at 6 months and adverse events [2]. In a substudy with detailed cognitive assessment, the groups were similar [3].

The TTM Trial has been criticized for imbalances between groups, the long time to reaching target temperature, poor temperature control, the short time to basic cardiopulmonary resuscitation and that wide inclusion criteria might have missed subgroups with potential benefit of the lower temperature. Regarding baseline differences, the adjusted analyses moved the point estimate of the intervention in direction benefit for the $36^{\circ} \mathrm{C}$ group (hazard ratio 1.14, $p=0.18$ ) [2]. The time to reach a temperature below $34^{\circ} \mathrm{C}$ was similar to large registries [4] and faster than the most influential previous randomized trial [5]. Temperature depicted with \pm 2 standard deviations will visually give an impression of imprecision,

Department of Anesthesiology and Intensive Care, Helsingborg Hospital, Helsingborg, Sweden; Department of Clinical Sciences, Lund University, Lund, Sweden 


\section{References}

1. Nielsen N, Wetterslev J, al-Subaie N, et al: Target temperature management after out-of-hospital cardiac arrest - a randomized, parallel-group, assessor-blinded clinical trial - rationale and design. Am Heart J 2012, 163(4):541-8.

2. Nielsen N, Wetterslev J, Cronberg T, Erlinge D, Gasche Y, Hassager C, et al: Targeted temperature management at 33 degrees $C$ versus 36 degrees C after cardiac arrest. N Engl J Med 2013, 369(23):2197-206.

3. Lilja G, Nielsen N, Friberg H, Horn J, Kjaergaard J, Nilsson F, et al: Cognitive function in survivors of out-of-hospital cardiac arrest after target temperature management at $33^{\circ} \mathrm{C}$ versus $36^{\circ} \mathrm{C}$. Circulation 2015, 131(15):1340-1349.

4. Nielsen N, Hovdenes J, Nilsson F, Rubertsson S, Stammet P, Sunde K, et al: Outcome, timing and adverse events in therapeutic hypothermia after out-of-hospital cardiac arrest. Acta Anaesth Scand 2009, 53(7):926-34.

5. Hypothermia after Cardiac Arrest Study Group: Mild therapeutic hypothermia to improve the neurologic outcome after cardiac arrest. N Engl J Med 2002, 346(8):549-56.

6. Zeiner A, Holzer M, Sterz F, Schorkhuber W, Eisenburger P, Havel C, et al: Hyperthermia after cardiac arrest is associated with an unfavorable neurologic outcome. Arch Intern Med 2001, 161(16):2007-12.

7. Annborn M, Bro-Jeppesen J, Nielsen N, Ullen S, Kjaergaard J, Hassager C, et al: The association of targeted temperature management at 33 and 36 degrees $C$ with outcome in patients with moderate shock on admission after out-of-hospital cardiac arrest: a post hoc analysis of the Target Temperature Management trial. Intensive Care Med 2014, 40(9):1210-9.

doi:10.1186/1471-227X-15-S1-A3

Cite this article as: Nielsen: Results and generalizability of the Target Temperature Management Trial and future research for patients admitted to intensive care after cardiac arrest. BMC Emergency Medicine 2015 15(Suppl 1):A3.

\section{Submit your next manuscript to BioMed Central and take full advantage of:}

- Convenient online submission

- Thorough peer review

- No space constraints or color figure charges

- Immediate publication on acceptance

- Inclusion in PubMed, CAS, Scopus and Google Scholar

- Research which is freely available for redistribution

Submit your manuscript at www.biomedcentral.com/submit 